vigorously pursued as part of planned policy at district and regional levels. This is urgently required in view of the unmet patient needs, increased teaching demands and the move to community care.

Psychotherapy Specialist Section Working Group: Sandra Grant, Frank Margison and Andrew Powell

Approved by Council

June 1990

\section{References}

(1) Norms for medical staffing of a psychotherapy service for a population of 200,000 . News and Notes, British Journal of Psychiatry, October 1975.

(2) RAWNSLEY, K. (1984) The future of the consultant in psychiatry. Bulletin of the Royal College of Psychiatrists, 8, 7 .

(3) Ashurst, P. (1987) Psychotherapy Specialist Section: survey of members. Bulletin of the Royal College of Psychiatrists, 11, 5.

(4) Handbook of the Joint Committee on Higher Psychiatric Training (1990 edition).

(5) Psychiatric Beds and Resources: Factors Influencing Bed Use and Service Planning (1988) Report of the Section for Social and Community Psychiatry. London: Gaskell (Royal College of Psychiatrists).
(6) Report of the Working Group on the Training Implications of the Move towards Community Oriented Treatment. Royal College of Psychiatrists.

(7) Survey of Consultant Psychotherapists for the Consultant Psychotherapist Conference (1989) Unpublished.

(8) Hopkins, P. (1987) Michael Balint: the man and his work. Psychiatry in Practice, 6, 4.

(9) Guidelines for the training of general psychiatrists in psychotherapy (1986) Bulletin of the Royal College of Psychiatrists, 10, 10.

(10) The teaching of clinical psychopathology (1985) AUTP Newsletter, (Summer) p. 39-44.

(11) The Tavistock Clinic: Professional Training and Development Programmes 1990/1991. Tavistock and Portman Clinics Special Committee.

(12) Joint Planning and Advisory Committee. September 1987.

(13) Fourth Report of the Korner Steering Group on Health Services Information.

(14) Report of the Child and Adolescent Psychiatry Section, Working Group on the Development of Child Psychotherapy Services in the UK (1989).

(15) Report of the Psychotherapy Section, Working Group on the Profession of Adult Psychotherapist in the NHS.

(16) Psychological Therapy Services: the Need for Organisational Change (1989) British Psychological Society Division of Clinical Psychology, Service Development Sub-Committee Consultation Document.

(17) Griffiths, R. (1987) Community Care: An Agenda for Action. HMSO.

\title{
Special (Career Counselling) Committee
}

Council has approved the establishment of a Special Committee with the following remit:

"To provide counselling to any individual pursuing a psychiatric career in the British Isles who believes that his/her career is being impeded by discrimination or disadvantage. It is anticipated that the individual will normally have made full use of counselling and advice resources available at a local level, including those provided by the Regional Postgraduate Dean. It is not intended to deal with issues connected with the Membership Examination".

The intention is to assist individuals in making rational choices about their future careers in their particular circumstances and to advise appropriate authorities where there is evidence of discrimination or handicap.

In future, all units will have a Clinical Tutor and each psychiatric training scheme has a Psychiatric
Tutor who may be consulted for career advice. All staff in training should receive regular career counselling. The College Regional Adviser and the Regional Postgraduate Dean are also available to offer advice.

Anyone whose problems are not resolved by full use of these facilities may approach the Special Committee. In this case the individual should write to the President, setting out a brief account of the nature of his/her difficulties. Should the President decide that this is a proper matter for the Special Committee, the secretary will request a more detailed statement, including the names of those whose advice has already been sought.

The matter will then be considered by two members of the Committee who may arrange to interview the individual and agree appropriate further action. 